\title{
Association of serum 25-Hydroxyvitamin D with Vitamin D intervention and outdoor activity among children in North China: an observational study
}

Xuguang Zhang ${ }^{1}$, Yanping Chen ${ }^{1}$, Shanshan Jin², Xinxin Bi³ , Dongkai Chen', Dongmei Zhang ${ }^{1}$, Li Liu', Hong Jing ${ }^{1}$ and Lixin $\mathrm{Na}^{2^{*}}$

\begin{abstract}
Background: Living at high latitudes is one of the risk factors for vitamin D deficiency in children. However, evidence on vitamin D improvement for this pediatric population to date is limited. This study aims at evaluating the association of different vitamin D intervention methods and outdoor activity on the vitamin D status of children in North China.
\end{abstract}

Methods: In this observational study, a total of 55,925 children aged 1 month to 18 years old were recruited from pediatric outpatient departments from July 2016 to June 2017. Data on demographics, anthropometric measurements, vitamin $\mathrm{D}$ intervention (either prescribed by physicians or given by parents) and outdoor activity were recorded. The serum levels of 25-hydroxycholecalciferol $(25(\mathrm{OH}) \mathrm{D})$ were determined by high performance liquid chromatography tandem-mass spectrometry. Logistic regression analysis was performed to assess the association of vitamin D intervention or outdoor activity with blood vitamin D status, adjusted for age, gender, BMI for age, and seasons.

Results: The overall rate of hypovitaminosis D was $65.60 \%$. Of the children's outdoor activity, $35.63,31.95$, and $32.42 \%$ were below $30 \mathrm{~min} / \mathrm{d}, 30-60 \mathrm{~min} / \mathrm{d}$ and over $60 \mathrm{~min} / \mathrm{d}$, respectively. Furthermore, the proportion of therapeutic intervention, supplementation intervention and no vitamin $D$ intervention among the children was 16.48, 32.87, and 50.65\%, respectively. After adjusted for confounding factors, vitamin D intervention was associated with a lower risk of hypovitaminosis D, with OR $(95 \% \mathrm{Cl})$ of $0.191(0.180,0.202)$ in children with therapeutic doses and $0.423(0.404,0.443)$ in those with supplementation doses, compared with children without vitamin D intervention. In addition, longer outdoor time was associated with a lower risk of hypovitaminosis D [0.479 (0.456, $0.504)$ for $60 \mathrm{~min} / \mathrm{d}, 0.737(0.701,0.776)$ for 30-60 $\mathrm{min} / \mathrm{d}]$, independent of vitamin D intervention.

(Continued on next page)

\footnotetext{
*Correspondence: nalixin2003@163.com

${ }^{2}$ Collaborative Innovation Center for Biomedicine, Medical Technology

College, Shanghai University of Medicine \& Health Sciences, Shanghai 201318, China

Full list of author information is available at the end of the article
}

(c) The Author(s). 2020 Open Access This article is licensed under a Creative Commons Attribution 4.0 International License, which permits use, sharing, adaptation, distribution and reproduction in any medium or format, as long as you give appropriate credit to the original author(s) and the source, provide a link to the Creative Commons licence, and indicate if changes were made. The images or other third party material in this article are included in the article's Creative Commons licence, unless indicated otherwise in a credit line to the material. If material is not included in the article's Creative Commons licence and your intended use is not permitted by statutory regulation or exceeds the permitted use, you will need to obtain permission directly from the copyright holder. To view a copy of this licence, visit http://creativecommons.org/licenses/by/4.0/ The Creative Commons Public Domain Dedication waiver (http://creativecommons.org/publicdomain/zero/1.0/) applies to the data made available in this article, unless otherwise stated in a credit line to the data. 


\begin{abstract}
(Continued from previous page)
Conclusions: High prevalence of vitamin D deficiency was found in children living at high latitudes. Vitamin D intervention and outdoor activity are all negatively associated with children's vitamin D deficiency. Routine vitamin D intervention combined with increased outdoor time might be an effective approach to prevent hypovitaminosis D among children, especially those at school, living at high latitudes.
\end{abstract}

Keywords: Vitamin D, Therapeutic intervention, Supplementation intervention, Outdoor activity, Children, North China

\section{Background}

Vitamin D deficiency is a disease mainly induces disorders of calcium and phosphorus metabolism, which causes defective chondrocyte differentiation, mineralization in growth plate and defects in osteoid mineralization among children [1]. Vitamin D deficiency is also related to functions of muscles and immune organs, and hematopoiesis, which are associated with multiple extra-skeletal disorders, such as myopathy, anemia, and recurrent respiratory tract infections in children [2-4].

Vitamin D deficiency or insufficiency are still of global public health concerns, particularly in developing countries [5]. Approximately $30 \%$ of children suffer from hypovitaminosis D worldwide [6]. Academic societies of China and other regions have released guidelines to emphasize the role of outdoor time and vitamin D intervention (routine vitamin $\mathrm{D}$ supplementation in the first year of life and for those aged 1-18 years with risk factors for vitamin D deficiency) in physical health of children and adolescents $[7,8]$. Several studies have demonstrated that vitamin $\mathrm{D}$ intervention significantly increased blood 25-hydroxyvitamin D (25(OH)D) level in children. A randomized, double-blinded study reported that vitamin $\mathrm{D}$ treatment in $600 \mathrm{IU} / \mathrm{d}$ for 6 weeks resulted in an increase in serum $25(\mathrm{OH}) \mathrm{D}$ in asthmatic children compared with placebo treatment (76.3 vs $48.2 \mathrm{nmol} / \mathrm{l}$ ) [9]. In a prospective observational study, 55 children with inflammatory bowel diseases were prescribed vitamin D $2000 \mathrm{IU} / \mathrm{d}$ for 2 to 3 months, and their serum $25(\mathrm{OH})$ D were increased from 58 $\mathrm{nmol} / \mathrm{L}$ at the baseline to $85 \mathrm{nmol} / \mathrm{L}$. [10] Uysalol et al. found that serum $25(\mathrm{OH}) \mathrm{D}$ levels in asthmatic children with inadequate sun exposure and vitamin $\mathrm{D}$ intervention were significantly lower than that of the healthy controls (16.6 vs $28.2 \mathrm{ng} / \mathrm{mL}$ ) in Turkey [11]. Therefore, most present studies focused on the impact of vitamin D intervention and outdoor time on pediatric patients. Yet the association of vitamin $\mathrm{D}$ intervention and sun exposure on healthy children are not well documented given that few guidelines support serum $25(\mathrm{OH}) \mathrm{D}$ test for children [12]. However, previous studies suggested that circulating vitamin D level should be measured even in healthy children with a risk of vitamin $D$ deficiency mainly due to inadequate sun exposure [13, 14], in order to early prevent vitamin D deficiency-related diseases.
Constant exposure of many parents to information on benefits of vitamin $\mathrm{D}$ supplementation during pregnancy and throughout childhood may contribute to voluntary daily intake of vitamin D in children $[15,16]$. Supplementation intervention of vitamin $\mathrm{D}$ helps prevent vitamin D deficiency in children, although few studies have been reported [17]. With the spread of child health education, children are more likely to have regular clinic visits due to early recognition of nutritional ricketsrelated clinical symptoms by their parents, e.g. frontal bossing, rachitic rosary, and leg deformity. 25(OH) D test is routinely performed for children in North China as part of physical examination or assessment of suspected nutritional rickets. Once the diagnosis is confirmed, individualized intervention is provided by physicians/doctors to maintain or improve vitamin D status of their pediatric patients. Nevertheless, little research has been conducted on efficacy and feasibility of therapeutic intervention to date. In our study, data of 55,925 children from our clinic were analyzed to investigate their vitamin $\mathrm{D}$ nutriture and possible causes, of which vitamin $\mathrm{D}$ intervention and outdoor time were of particular interest, to explore the necessity of regular monitoring of $25(\mathrm{OH})$ D status and intervention in children living at high latitudes.

\section{Methods}

Study design, data source, and patient selection

Heilongjiang is a province comprising 12 cities including Harbin, located in North China at latitude $43^{\circ} 3^{\prime}-53^{\circ} 3^{\prime}$ $\mathrm{N}$ and known as the coldest region in China, with an average annual sunshine of 1874 to $2761 \mathrm{~h}$ in 2016 2017, according to Heilongjiang Bureau of Statistics. The Sixth National Population Census of China indicated that the resident population in Heilongjiang was 38.31 million, in which 4.57 million (11.94\%) were aged 0-14 years old.

In China, child health is a branch of pediatric medicine mainly dealing with physical examination and health assessment on infants and young children including growth and the behavioral development assessment, feeding guidance, assessment of nutritional status, micronutrient testing, as well as diagnosis and treatment of rickets. In this cross-sectional study, children aged 0-18 years old were recruited who visited child health clinic in 
Harbin Children's Hospital between July 2016 and June 2017. All guardians completed questionnaires involving questions of their children's name, date of birth, date of visit, ethnic, and vitamin $\mathrm{D}$ intervention.

Therapeutic intervention is defined as vitamin D prescription in children who had physical examination or clinic visits in the past 3-6 months. Prophylactic and therapeutic dosage was recommended for children with a normal level and in vitamin D deficiency, respectively according to the consensus of the Chinese Society of Osteoporosis and Bone Mineral Research [18], respectively (most of them had oral vitamin D3 intake of 800-2400 IU/d). Supplementation intervention is defined as daily vitamin D intake in children asked by their parents in last 3-6 months (most of them had oral vitamin D3 intake of 400-800 IU/d), without being monitored for their serum $25(\mathrm{OH}) \mathrm{D}$ or a prescription from doctors. No vitamin D intervention was defined as taking no vitamin D supplements in the past 3-6 months. Children were considered being supplemented with vitamin $\mathrm{D}$ if they were 1) aged over 6 months and given either therapeutic or supplementation vitamin D intervention for more than 3 months and 2) aged less than 6 months and received vitamin $\mathrm{D}$ intervention in either aforementioned way for $>1$ month. Children with the following conditions were excluded from our study: 1) using vitamin D metabolites and their analogs, e.g., alfacalcidol or calcitriol, for their routine supplementation. 2) suffering from hypophosphatemic rickets, organ dysfunction, congenital disorders, inherited metabolic diseases, acute infectious diseases and chronic inflammatory disease. 3) for those over 6 months old, either aforementioned intervention suspended for $>20$ $\mathrm{d}$ in the past 3 months and 4) for children under 6 months, either aforementioned intervention suspended for $>10 \mathrm{~d}$ in the past 1 month. Detailed information on the nature of this study was provided to the parents or guardians of participants before consent was written.

\section{Outdoor activity}

The questionnaire about outdoor activity time included the average frequency of outdoor activity per week in the past 3 months ( 1 to 7 days), duration per day (less than $30 \mathrm{~min} /$ day, $30 \sim 60 \mathrm{~min} /$ day and more than 60 $\mathrm{min} /$ day) and activity window (before 8 a.m., 8 a.m. to 4 p.m. and post 4 p.m.). Outdoor activity from 8 a.m. to 4 p.m. was considered as being associated with vitamin status and investigated. Pre-investigation of 50 randomly-selected parents was conducted and repeated 1 week afterwards, resulting in the reliability coefficient $r=0.912$.

\section{Anthropometric measurements}

Trained nurses measured twice the height and weight of the enrolled children within $0.1 \mathrm{~cm}$ and $0.1 \mathrm{~kg}$ respectively, and average the measurements for the final value.
An anthropometric calculator obtained from World Health Organization (http://www.who.int/en/) was used to determine body mass index (BMI) for age. BMI for age $<90$ percentile was considered normal, 90-97 percentile overweight and $>97$ percentile obese.

\section{Circulating 25(OH) D level}

Blood samples $(3 \mathrm{ml})$ were taken by antecubital venipuncture and then stored in a cool box for $<2 \mathrm{~h}$. After centrifugation at room temperature for $10 \mathrm{~min}$ at $1200 \times g$, the upper serum pipetted and stored at $4{ }^{\circ} \mathrm{C}$ for $<24 \mathrm{~h}$. The samples were kept at room temperature for 30 min before analysis. The serum 25(OH) D levels were determined by high performance liquid chromatography tandem-mass spectrometry (HPLC-MS/MS, API 3200; AB SCIEX, American). The lower limits of 25-(OH)D2 and $25-(\mathrm{OH}) \mathrm{D} 3$ for detection were both $1.6 \mathrm{ng} / \mathrm{mL}$. The test sensitivity was assessed with the inter-batch coefficient of variation $(\mathrm{CV})$ of $6.59 \%$ and between batches CV of $6.98 \%$.

\section{Diagnostic criteria of serum Vitamin D status}

The consensus of the Chinese Society of Osteoporosis and Bone Mineral Research, Chinese Medical Association indicated that circulating $25(\mathrm{OH}) \mathrm{D}<10 \mathrm{ng} / \mathrm{mL}$ was considered severely deficient, $10-20 \mathrm{ng} / \mathrm{mL}$ deficient, $20-29 \mathrm{ng} / \mathrm{mL}$ insufficient, and $\geq 30 \mathrm{ng} / \mathrm{mL}$ sufficient [18]. High levels of circulating $25(\mathrm{OH}) \mathrm{D}$ may have benefits for children's extraskeletal organs [19]. Thus, the cut-off points for defining low status of vitamin $\mathrm{D}$ is $30 \mathrm{ng} / \mathrm{mL}$, which refers to hypovitaminosis D in this study [14].

\section{Statistical analysis}

The serum level of $25(\mathrm{OH}) \mathrm{D}$ was expressed as mean \pm SD. Comparison of the $25(\mathrm{OH})$ D levels between different groups was determined by ANOVA. The prevalence of vitamin $\mathrm{D}$ status was expressed as $n(\%)$. The statistical difference of the prevalence of vitamin D status between different groups was determined by chi-square test. Logistic regression analysis was performed to evaluate the association of risk factors with blood vitamin $\mathrm{D}$ status. Furthermore, the associations of hypovitaminosis $\mathrm{D}$ with vitamin $\mathrm{D}$ intervention and outdoor time was examined after adjustment for age, gender, BMI for age, and season. Data were expressed as odds ratio (OR) and 95\% confidence interval (CI). All analyses were performed using SPSS 21.0. A $p$ value $<0.05$ was considered statistically significantly.

\section{Results}

Participant characteristics

A total of 55,925 participants from the 12 cities of Heilongjiang were included in this study, in which 30, $683(54.86 \%)$ were male. Table 1 presented the basic 
characteristics of the participants. The average serum level of $25(\mathrm{OH})$ D for all participants was $26.13 \pm$ $12.30 \mathrm{ng} / \mathrm{mL}$. The median age of participants was 3.10 years old (interquartile range, 1.10-6.50 years old). The highest level of serum vitamin D was found in the group younger than 1 year old. As the age increased, the serum vitamin $\mathrm{D}$ level was dropped, which remained $16.24 \pm 8.30 \mathrm{ng} / \mathrm{mL}$ in children aged from 12 to younger than 18 years old. The serum vitamin $\mathrm{D}$ levels in normal-weight, overweight and obese children were $26.58 \pm 12.26 \mathrm{ng} / \mathrm{mL}, 21.84 \pm$ $12.43 \mathrm{ng} / \mathrm{mL}$ and $20.07 \pm 9.90 \mathrm{ng} / \mathrm{mL} \quad(P<0.001)$, respectively, indicating the deterioration in vitamin $D$ status with increasing body weight in children. Children had the lowest level of vitamin D (25.37 \pm
$11.95 \mathrm{ng} / \mathrm{mL}, \quad P<0.001)$ in winter than in other seasons of the year. There was no significant difference of serum vitamin D between the Han children and the minority peers $(26.12 \pm 12.29$ vs $26.91 \pm$ $12.67 \mathrm{ng} / \mathrm{mL}, P=0.050)$. Of the children's outdoor time, $35.63,31.95$, and $32.42 \%$ were below $30 \mathrm{~min} / \mathrm{d}$, $30-60 \mathrm{~min} / \mathrm{d}$ and over $60 \mathrm{~min} / \mathrm{d}$, respectively. Children with more than $60 \mathrm{~min} / \mathrm{d}$ outdoor activity had the highest level of serum vitamin D $(29.60 \pm 12.11$ $\mathrm{ng} / \mathrm{mL}, P<0.001$ ). Furthermore, $50.65 \%$ of the subjects were not given vitamin $D$ intervention $(20.60 \pm$ $8.65 \mathrm{ng} / \mathrm{mL}), 32.87 \%$ received vitamin D supplementation $(29.80 \pm 9.49 \mathrm{ng} / \mathrm{mL})$ and $16.48 \%$ were provided therapeutic doses of vitamin $\mathrm{D}(35.80 \pm 17.14$ $\mathrm{ng} / \mathrm{mL}, P<0.001)$.

Table 1 25(OH) D concentration in children aged $0-18$ years old

\begin{tabular}{|c|c|c|c|}
\hline & N (\%) & 25(OH) D (ng/mL) & $P$ value \\
\hline Total & 55,925 & $26.13 \pm 12.30$ & \\
\hline Gender & & & $<0.001$ \\
\hline Boys & $30,683(54.86)$ & $26.42 \pm 12.07$ & \\
\hline Girls & $25,241(45.13)$ & $25.78 \pm 12.56$ & \\
\hline Age (year) & & & $<0.001$ \\
\hline $0<$ age $<1$ & $11,953(21.37)$ & $33.25 \pm 13.64$ & \\
\hline $1 \leq$ age $<3$ & $14,901(26.64)$ & $30.71 \pm 11.44$ & \\
\hline $3 \leq$ age $<6$ & $13,124(23.47)$ & $23.74 \pm 9.37$ & \\
\hline $6 \leq$ age $<12$ & $12,416(22.20)$ & $19.12 \pm 8.70$ & \\
\hline $12 \leq$ age $<18$ & $3531(6.31)$ & $16.24 \pm 8.30$ & \\
\hline Season & & & $<0.001$ \\
\hline Spring & $15,795(28.24)$ & $25.98 \pm 11.77$ & \\
\hline Summer & $17,421(31.15)$ & $26.58 \pm 13.07$ & \\
\hline Autumn & $10,205(18.25)$ & $26.51 \pm 12.08$ & \\
\hline Winter & $12,504(22.36)$ & $25.37 \pm 11.95$ & \\
\hline Ethnic & & & 0.050 \\
\hline Han & $54,967(98.29)$ & $26.12 \pm 12.29$ & \\
\hline Ethnic minorities in China & $958(1.71)$ & $26.91 \pm 12.67$ & \\
\hline Outdoor time & & & $<0.001$ \\
\hline$<30 \mathrm{~min} / \mathrm{d}$ & $19,929(35.63)$ & $21.61 \pm 11.81$ & \\
\hline $30-60 \mathrm{~min} / \mathrm{d}$ & $17,867(31.95)$ & $27.65 \pm 11.47$ & \\
\hline$>60 \mathrm{~min} / \mathrm{d}$ & $18,129(32.42)$ & $29.60 \pm 12.11$ & \\
\hline BMl for age & & & $<0.001$ \\
\hline Normal & $51,294(91.72)$ & $26.58 \pm 12.26$ & \\
\hline Overweight & $2851(5.10)$ & $21.84 \pm 12.43$ & \\
\hline Obesity & $1780(3.18)$ & $20.07 \pm 9.90$ & \\
\hline Intervention & & & $<0.001$ \\
\hline None & $28,328(50.65)$ & $20.60 \pm 8.65$ & \\
\hline Supplementation intervention & $18,383(32.87)$ & $29.80 \pm 9.49$ & \\
\hline Therapeutic intervention & $9214(16.48)$ & $35.80 \pm 17.14$ & \\
\hline
\end{tabular}




\section{Characteristics of children with different Vitamin D statuses}

The overall rate of hypovitaminosis D was $65.60 \%$. 6.57, 25.51 , and $33.52 \%$ of the children included were found with severe deficiency, deficiency and insufficiency, respectively. Moreover, $18.11 \%$ children with severe deficiency were overweight or obese, compared with 11.34 and $8.17 \%$ in those with deficiency and insufficiency, respectively. However, the rate of overweight and obesity decreased to $4.21 \%$ in children with vitamin D sufficiency $(P<0.001)$. Children who have outdoor time of $30-60 \mathrm{~min} / \mathrm{d}$ and over $60 \mathrm{~min} / \mathrm{d}$ showed a percentage of 34.31 and $39.97 \%$ in the vitamin D sufficiency group, whereas it dropped to $25.72 \%$ in the $<30 \mathrm{~min} / \mathrm{d}$ group $(P<0.001)$. In children with normal vitamin $D$ status, 46.70 and $27.12 \%$ had supplementation and therapeutic doses of vitamin D, respectively; in contrast, $26.18 \%$ received no intervention, accounting for $90.31 \%$ patients with severe vitamin $\mathrm{D}$ deficiency (Table 2).

\section{Association of Risk Factors with Vitamin D status}

With the logistic regression model, we analyzed the risk factors including gender, age, ethnics, BMI for age, season, outdoor time and vitamin $\mathrm{D}$ intervention for prediction of hypovitaminosis $\mathrm{D}$ in all the participants (Table 3). The results showed that among the influential factors, female $(\mathrm{OR}=1.155, \quad P<0.001$, relative to males), older ages $(1 \leq$ age $<3$, OR $=1.534$,
$P<0.001 ; 3 \leq$ age $<6, \quad$ OR $=5.779, \quad P<0.001 ; 6 \leq$ age $<$ $12, \mathrm{OR}=12.685, P<0.001 ; 12 \leq$ age $<18, \mathrm{OR}=15.932$, $P<0.001$; relative to those younger than 1 years old), overweight and obesity $(\mathrm{OR}=1.219, P<0.001$, relative to normal) and winter $(\mathrm{OR}=1.189, P<0.001$, relative to summer) were associated with an increased risk of hypovitaminosis D. In contrast, increased outdoor activity time $(30-60 \mathrm{~min} / \mathrm{d}, \mathrm{OR}=0.756, P<0.001 ;>60$ $\mathrm{min} / \mathrm{d}, \quad$ OR $=0.482, \quad P<0.001 ;$ relative to $<30 \mathrm{~min} / \mathrm{d}$ ) and vitamin $\mathrm{D}$ intervention (supplementation intervention, $\mathrm{OR}=0.416, P<0.001$; therapeutic intervention, $\mathrm{OR}=0.183, P<0.001$; relative to no intervention) were associated with an decreased risk of hypovitaminosis D.

\section{Association of Intervention Methods with Vitamin D status}

After adjusting for age, sex, BMI for age, season, and outdoor activity time, an inverse association of vitamin $\mathrm{D}$ intervention with hypovitaminosis D was observed. The OR (95\% CI) of hypovitaminosis D was 0.423 $(0.404,0.443)$ in children with supplementation doses and $0.191(0.180,0.202)$ in children with therapeutic doses compared with children with no supplements (Table 4). After stratification by age group, the negative association of vitamin D interventions (including supplementation and therapeutic doses) with hypovitaminosis $\mathrm{D}$ existed in each age group (Supplement Table 1).

Table 2 Characteristics of children with varying serum levels of $25(\mathrm{OH}) \mathrm{D}$

\begin{tabular}{|c|c|c|c|c|c|}
\hline & Severe deficient & Deficient & Insufficient & Sufficient & $P$ value \\
\hline Vitamin D (ng/mL, $\left.{ }^{-} \mathrm{x} \pm \mathrm{s}\right)$ & $7.45 \pm 2.19$ & $15.35 \pm 2.87$ & $25.04 \pm 2.81$ & $38.74 \pm 10.57$ & $<0.001$ \\
\hline Percentage (\%) & 6.57 & 25.51 & 33.52 & 34.40 & \\
\hline Male (\%) & 51.20 & 53.07 & 55.42 & 56.34 & $<0.001$ \\
\hline Age (years, $\left.{ }^{-} x \pm s\right)$ & $7.54 \pm 4.99$ & $6.65 \pm 3.94$ & $4.18 \pm 3.38$ & $2.09 \pm 2.39$ & $<0.001$ \\
\hline Ethnic (Han, \%) & 98.31 & 98.49 & 98.28 & 98.14 & 0.063 \\
\hline Overweight and obesity (\%) & 18.11 & 11.34 & 8.17 & 4.21 & $<0.001$ \\
\hline Season (\%) & & & & & $<0.001$ \\
\hline Spring & 30.50 & 29.82 & 31.12 & 32.29 & \\
\hline Summer & 26.53 & 29.33 & 28.19 & 27.83 & \\
\hline Autumn & 16.31 & 17.35 & 18.69 & 18.85 & \\
\hline Winter & 26.66 & 23.50 & 22.00 & 21.03 & \\
\hline Outdoor activity time (\%) & & & & & $<0.001$ \\
\hline$<30 \mathrm{~min} / \mathrm{d}$ & 58.69 & 56.23 & 25.63 & 25.72 & \\
\hline $30-60 \mathrm{~min} / \mathrm{d}$ & 23.56 & 22.14 & 38.63 & 34.31 & \\
\hline$>60 \mathrm{~min} / \mathrm{d}$ & 17.75 & 21.63 & 35.74 & 39.97 & \\
\hline Intervention methods (\%) & & & & & $<0.001$ \\
\hline No intervention & 90.31 & 74.10 & 50.16 & 26.18 & \\
\hline Supplementation intervention & 7.27 & 17.94 & 35.06 & 46.70 & \\
\hline Therapeutic intervention & 2.43 & 7.96 & 14.79 & 27.12 & \\
\hline
\end{tabular}

${ }^{-} \mathrm{x} \pm \mathrm{s}$ and percentage (\%) were used to describe the continuous and categorical variables, respectively; $P<0.05$ was regarded as statistically significant 
Table 3 Regression analysis of risk factors for Hypovitaminosis D

\begin{tabular}{|c|c|c|}
\hline & OR $(95 \% \mathrm{Cl}, n=55,925)$ & $P$ Value \\
\hline \multicolumn{3}{|l|}{ Gender } \\
\hline Male & 1 & \\
\hline Female & $1.155(1.108,1.205)$ & $<0.001$ \\
\hline \multicolumn{3}{|l|}{ Age (years) } \\
\hline $0<$ age $<1$ & 1 & \\
\hline $1 \leq$ age $<3$ & $1.534(1.457,1.615)$ & $<0.001$ \\
\hline $3 \leq$ age $<6$ & $5.779(5.437,6.142)$ & $<0.001$ \\
\hline $6 \leq$ age $<12$ & $12.685(11.740,13.707)$ & $<0.001$ \\
\hline $12 \leq$ age $<18$ & $15.932(13.738,18.476)$ & $<0.001$ \\
\hline \multicolumn{3}{|l|}{ Ethnic group } \\
\hline Han & 1 & \\
\hline Other & $1.709(0.923,1.260)$ & 0.341 \\
\hline \multicolumn{3}{|l|}{ BMl for age } \\
\hline Normal & 1 & \\
\hline Overweight and obesity & $1.219(1.046,1.421)$ & $<0.001$ \\
\hline \multicolumn{3}{|l|}{ Season group } \\
\hline Summer & 1 & \\
\hline Spring & $1.079(1.017,1.145)$ & 0.141 \\
\hline Autumn & $0.957(0.903,1.015)$ & 0.012 \\
\hline Winter & $1.189(1.113,1.270)$ & $<0.001$ \\
\hline \multicolumn{3}{|l|}{ Outdoor time } \\
\hline$<30 \mathrm{~min} / \mathrm{d}$ & 1 & \\
\hline $30-60 \mathrm{~min} / \mathrm{d}$ & $0.756(0.718,0.797)$ & $<0.001$ \\
\hline$>60 \mathrm{~min} / \mathrm{d}$ & $0.482(0.458,0.508)$ & $<0.001$ \\
\hline \multicolumn{3}{|l|}{ Intervention } \\
\hline None & 1 & \\
\hline Supplementation intervention & $0.416(0.396,0.437)$ & $<0.001$ \\
\hline Therapeutic intervention & $0.183(0.173,0.194)$ & $<0.001$ \\
\hline
\end{tabular}

\section{Association of the Intervention Methods with Vitamin D status in children with varying outdoor time}

We conducted logistic regression to further eliminate the influence of outdoor activity time on the relationship between intervention methods and serum 25(OH) D level. Both therapeutic and supplementation intervention reduced the risk of hypovitaminosis D regardless of outdoor time compared to those with no vitamin $\mathrm{D}$ intervention. In children whose outdoor time was $>60 \mathrm{~min} / \mathrm{d}$, the OR was $0.196(0.178,0.216)$ in the former way, whereas $0.508(0.470,0.550)$ in the latter way, compared with those who were not given intervention (Table 5).

\section{Association of Outdoor Time with Vitamin D status}

We found another inverse association of prolonged outdoor time with hypovitaminosis D after age, sex, BMI for age, season, and intervention methods were adjusted. The OR (95\% CI) of hypovitaminosis D was 0.737 $(0.701,0.776)$ in children with outdoor time of $30-60$ $\mathrm{min} / \mathrm{d}$ and $0.479(0.456,0.504)$ in those with $60 \mathrm{~min} / \mathrm{d}$ compared to those with less than $30 \mathrm{~min}$ (Table 6). Besides, after age stratification, prolonged outdoor time was negatively associated with hypovitaminosis D in all age groups (Supplement Table 2).

\section{Discussion}

This observational study was the first to assess circulating $25(\mathrm{OH}) \mathrm{D}$ in over 50,000 children by HPLC-MS/ MS, the current gold standard in vitamin D level assessment [20]. Our data showed that (1) hypovitaminosis D was prevalent (65.60\%) among children in Heilongjiang; (2) older ages, winter and overweight and obesity were risk factors for pediatric hypovitaminosis D. (3) supplementation and therapeutic vitamin $\mathrm{D}$ intervention were inversely associated with the rates of pediatric hypovitaminosis D; (4) increased outdoor activity time was also linked with a lower risk of hypovitaminosis D, and (5) vitamin $\mathrm{D}$ intervention combined with outdoor time over $60 \mathrm{~min} / \mathrm{d}$ may be a better way in preventing hypovitaminosis D among children in North China.

In this study, there was no significant difference of serum vitamin D between Han children and the minority group. This corresponds with a cross-sectional study involving 14,473 children aged $6 \sim 17$ years old from 31 provinces in China $(48.1 \mathrm{nmol} / \mathrm{L}$ in Han children and $49.3 \mathrm{nmol} / \mathrm{L}$ in minority children, $P=0.587$ ) [21]. Overweight and obesity are among the widely accepted risk factors for the serum vitamin D level. Overweight and obese children tend to live a sedentary life. Moreover, vitamin D through supplementation or cutaneous synthesis is volumetrically diluted and isolated by adipose tissues, possible resulting in the low serum vitamin $D$ level in this population [22]. In addition, we also found that hypovitaminosis D was prevalent in older children, and infants had the highest level of mean serum $25(\mathrm{OH})$ D $(33.25 \pm 13.64 \mathrm{ng} / \mathrm{ml})$. However, childhood vitamin D

Table 4 Association of vitamin D intervention with hypovitaminosis D

\begin{tabular}{|c|c|c|c|}
\hline Intervention & Model 1 & Model 2 & Model 3 \\
\hline No intervention & 1 & 1 & 1 \\
\hline Supplementation intervention & $0.435(0.415,0.455)$ & $0.435(0.415,0.455)$ & $0.423(0.404,0.443)$ \\
\hline Therapeutic intervention & $0.202(0.191,0.214)$ & $0.202(0.191,0.214)$ & $0.191(0.180,0.202)$ \\
\hline
\end{tabular}

Associations were examined with multivariable logistic regression. Model 1: adjusted for age and sex. Model 2: adjusted for BMI for age on the basis of model 1. Model 3: adjusted for season and outdoor time on the basis of model 2 
Table 5 Logistic regression analysis of the association of vitamin D intervention methods with hypovitaminosis D in children with varying outdoor time

\begin{tabular}{llll}
\hline Intervention methods & Model 1 & Model 2 & Model 3 \\
\hline$>60$ min/d & 1 & 1 & 1 \\
No intervention & $0.508(0.470,0.549)$ & $0.508(0.469,0.549)$ & $0.508(0.470,0.550)$ \\
$\begin{array}{l}\text { Supplementation intervention } \\
\text { Therapeutic intervention }\end{array}$ & $0.196(0.177,0.216)$ & $0.196(0.177,0.216)$ & $0.196(0.178,0.216)$ \\
$30-60$ min/d & 1 & 1 & 1 \\
No intervention & $0.362(0.332,0.394)$ & $0.362(0.332,0.394)$ & $0.361(0.332,0.394)$ \\
Supplementation intervention & $0.183(0.164,0.205)$ & $0.184(0.164,0.205)$ & $0.183(0.164,0.205)$ \\
Therapeutic intervention & & & 1 \\
$<30$ min/d & 1 & 1 & $0.377(0.346,0.411)$ \\
No intervention & $0.376(0.345,0.411)$ & $0.377(0.346,0.411)$ & $0.174(0.159,0.192)$ \\
Supplementation intervention & $0.176(0.160,0.194)$ & $0.174(0.159,0.192)$ & \\
Therapeutic intervention & & & 1 \\
\hline
\end{tabular}

Associations were examined using multivariable logistic regression. Model 1: adjusted for age and sex. Model 2: adjusted for BMI for age on the basis of model 1. Model 3: adjusted for season on the basis of model 2

nutritional status deteriorated with advancing age, which was in line with Korean and Canadian studies [23, 24]. Generally, outdoor activities and vitamin D supplementation in children younger than 3 years old depend on parental support, whereas those in school children older than 6 years are limited or encouraged by schools. Thus, we divided children's age into three groups and found that vitamin D intervention rate in group of age $0-3$ years $(66.89 \%)$ was higher than that of age 3-6 (42.04\%) and above 6 years old $(25.81 \%)$. The policy of physical examination by local communities is that regular physical examination free of charge is provided to children younger than 3 years old every 3-6 months and to those aged 3-6 years old every year, including screening for rickets and education on vitamin D supplementation. Nevertheless, routine physical examination is not performed in children older than 6 years old. Different health policy may be the main cause for high rate of vitamin D supplementation in younger children. Despite varying outdoor time and vitamin $\mathrm{D}$ interventions in each age group, an increase in outdoor time and vitamin $\mathrm{D}$ intervention present effectiveness in hypovitaminosis D prevention.

Latitude has a clear impact on the vitamin D status in children. However, we still lack of data for the vitamin D nutriture of children form different latitudes. Previous hospital-based cross-sectional studies indicated that 23.28\% children in Huzhou (southeastern China, 30 $2^{\circ}{ }^{\prime}-$ $31^{\circ} 1^{\prime} \mathrm{N}$ ) [25] and $33.60 \%$ in Hangzhou (southeastern China, $29^{\circ} 1^{\prime}-30^{\circ} 3^{\prime}$ N) [26] were found with hypovitaminosis $\mathrm{D}$, whereas the prevalence increased to $65.91 \%$ in this study, which is consistent with early research focusing on children in high latitudes. Data from Hutterite communities (Canada, $49^{\circ} 2^{\prime}-54^{\circ} 8^{\prime} \mathrm{N}$ ) suggested that $76.00 \%$ of children suffered from hypovitaminosis D [27], indicating that hypovitaminosis D might be a common and serious problem in children in high latitudes. Skin is a key organ in vitamin D synthesis because 80 $90 \%$ vitamin D that the human needs per day is produced in the skin from ultraviolet-B-activated 7dehydrocholesterol [28]. Evidence from Spain $\left(36^{\circ} 0^{\prime}-\right.$ $43^{\circ} 2^{\prime} \mathrm{N}$ ) suggested that production of over $1000 \mathrm{IU} / \mathrm{d}$ vitamin $\mathrm{D}$ in spring and summer depends on regular sunlight exposure [29], making outdoor activity an optimal way of getting vitamin D. However, our results showed that still 17.75 and $21.63 \%$ of the enrolled children whose outdoor time was over $60 \mathrm{~min} / \mathrm{d}$ had a deficient and insufficient vitamin D status, respectively. Moreover, excessive ultraviolet radiation exposure throughout childhood appears to be particularly harmful [30]. Children with sun protection by their parents are much less exposed to ultraviolet

Table 6 Logistic regression analysis of the association of outdoor time with hypovitaminosis D

\begin{tabular}{llll}
\hline Outdoor time $(\mathbf{m i n} / \mathbf{d})$ & Model 1 & Model 2 & Model 3 \\
\hline$<30$ & 1 & 1 & 1 \\
$30-60$ & $0.696(0.663,0.731)$ & $0.697(0.663,0.732)$ & $0.737(0.701,0.776)$ \\
$>60$ & $0.533(0.508,0.560)$ & $0.534(0.508,0.560)$ & $0.479(0.456,0.504)$
\end{tabular}

Associations were examined using multivariable logistic regression. Model 1: adjusted for age and sex. Model 2: adjusted for BMI for age on the basis of model 1. Model 3: adjusted for season and intervention methods on the basis of model 2 
radiation [31]. Therefore, vitamin D supplementation might be taken into account to prevent hypovitaminosis D among children living in Heilongjiang.

Numerous programs or health policies for vitamin D intervention are available in almost all countries to prevent vitamin $\mathrm{D}$ deficiency or hypovitaminosis $\mathrm{D}$ in children [32-35]. In the guidelines aforementioned, some risk factors for vitamin D deficiency are recognized, including vegan diet, malabsorption syndromes, and reduced sunlight exposure; meanwhile, regular vitamin D supplementation and routine $25(\mathrm{OH}) \mathrm{D}$ testing are recommended for children. However, living at high latitude as an identified risk factor for vitamin D deficiency has not been explicitly mentioned for routine $25(\mathrm{OH}) \mathrm{D}$ testing in these guidelines. Despite of high incidence of hypovitaminosis D among children living in high latitudes was found in previous studies [36], few of them focused on related improvements. Approximately $30 \%$ of the total world population lives from $40^{\circ} \mathrm{N}$ to $60^{\circ} \mathrm{N}$. Given the vitamin D status of children living at high latitudes, it is necessary to determine whether they need to be routinely screened for serum $25(\mathrm{OH})$ D levels, followed by appropriate vitamin D intervention as required. In this study, we found that hypovitaminosis D was prevalent in children living at high latitude, regardless of seasons or outdoor time. The vast majority of children maintaining adequate vitamin $\mathrm{D}$ status took vitamin D supplements. Therefore, despite the recommendations by some guidelines that populations at high risk of vitamin $\mathrm{D}$ deficiency should be routinely screened, the results of our study support regular vitamin $\mathrm{D}$ intervention for local children regardless of taking the $25(\mathrm{OH})$ D test. However, more future research is needed to confirm whether all children living at high latitudes should be given routine vitamin $\mathrm{D}$ intervention without $25(\mathrm{OH})$ D test.

The pediatric health care system in China has been improved and consists of a proper examination interval and routine monitor network of serum $25(\mathrm{OH}) \mathrm{D}$ levels in children [25, 37]. Prescriptions were given by health professionals according to vitamin D status and the supplementary recommendation in the consensus of the Chinese Society of Osteoporosis and Bone Mineral Research. To the best of our knowledge, this was the first study to describe and evaluate the association of therapeutic intervention on prevention of hypovitaminosis D among children, and therapeutic intervention had a 2.21-, and 5.24-fold decreased risk of hypovitaminosis D compared with supplementation intervention and no supplementation, respectively. Besides, health professionals urge the parents to keep regular vitamin D supplementation [38]. Minkowitz et al. reported that better adherence of guardians with low serum vitamin D levels to physicians' orders to remind their children of daily intake of vitamin supplements [39]. Although there were some unfavorable factors causing poor response to oral intervention [40], pediatricians could improve the oral doses according to the follow-up serum $25(\mathrm{OH})$ D test results until the doses reached optimum. Noticeably, however, compliance of children with follow-up blood collection varied. No vitamin D intervention due to guardians' lack of awareness that might be the main cause [38], was like to expose their children to the increased risk of hypovitaminosis $\mathrm{D}$ and acute and chronic diseases including infectious diseases, autoimmune disorders and childhood dental caries [41]. Thus, although therapeutic intervention has shown a better effect in preventing hypovitaminosis D than voluntary supplementation, which prevention strategy to follow depends on certain factors, in particular the local health policy and compliance of guardians with blood collection.

This study had several limitations. First, the vitamin D doses in the therapeutic group remained inconsistent. Individualized vitamin $\mathrm{D}$ intervention were prescribed by doctors according to the medical conditions of healthy children and those with vitamin D deficiency. Second, outdoor time might be a confounder. However, duration and sun-exposed skin areas of each child was not investigated in this study. Third, $<10-20 \%$ vitamin $\mathrm{D}$ that human needed per day was from diet [42], which played an important role in the vitamin D status of children. However, such information was unavailable in our study. We assumed that children in the same region had similar dietary patterns. A prospective study is warranted to explore the role of diet in addition to other confounders. Fourth, as the subjects in this study were all recruited from the outpatient department instead of the general pediatric population, their parents might be more concerned about their children's vitamin D status or health condition, and their health status may be better. Therefore, demographic characteristics of the participants in this study could not represent that of the whole population of children living in North China.

\section{Conclusions}

In summary, a large number of blood tests in our study demonstrated low vitamin D status in local children. Supplementation and therapeutic vitamin D intervention were all promising strategies and prolonged outdoor time was negatively associated with pediatric vitamin D deficiency, the combination of which might be an optimal way to prevent hypovitaminosis D in children; nevertheless, guardian's compliance might be considered for a practical prevention strategy. In addition, regardless of taking a $25(\mathrm{OH}) \mathrm{D}$ test, all children living at high latitudes might need routine vitamin $\mathrm{D}$ intervention. 


\section{Supplementary Information}

The online version contains supplementary material available at https://doi. org/10.1186/s12887-020-02435-9.

Additional file 1: Supplement Figure. Geographic characteristics of participants (city, number of subjects, \%).

Additional file 2: Supplement Table 1. Logistic regression analysis of the association of intervention methods with hypovitaminosis D in each age group.

Additional file 3: Supplement Table 2. Logistic regression analysis of the association of outdoor time with hypovitaminosis D in each age group.

\section{Abbreviations}

25(OH)D: 25-Hydroxycholecalciferol; BMI: Body mass index; OR: Odds ratio; HPLC-MS/MS: High performance liquid chromatography tandem-mass spectrometry

\section{Acknowledgements}

Technical assistance was provided by Heilongjiang Harmony Health Medical Laboratory.

\section{Authors' contributions}

$X Z$ and LN designed the study, writing, prepared the original draft, and acquired funding. $X Z, Y C, X B, D C, D Z$ and $L L$ collected the data; $H J$ and SJ analysed and interpreted data. All authors read and approved the final manuscript.

\section{Authors' information}

Not applicable.

\section{Funding}

This work was supported by the Health and Family Planning Commission of Heilongjiang Province (grant numbers 2017-234), and National Natural Science Foundation of China (grant numbers 81872614). The two funding organizations provide open access funding and are not involved in the conduct of the study, including the collection, analysis, and preparation of the data or the drafting, editing, review, or approval of the manuscript.

\section{Availability of data and materials}

The datasets used and/or analysed during the current study are available from the corresponding author on reasonable request.

\section{Ethics approval and consent to participate}

The study was conducted in accordance with the Declaration of Helsinki. Consent to participate was obtained from the parents/ guardians of the minors included in this study (minors are considered anyone under the age of 16). The protocol was approved by the Ethics Committee of Harbin Children's Hospital on May 17, 2016 (No. HRYLL 201605).

\section{Consent for publication}

Not applicable.

\section{Competing interests}

The authors declare that they have no competing interests.

\section{Author details}

'Department of Child Healthcare, Harbin Children's Hospital, Harbin 150010, China. ${ }^{2}$ Collaborative Innovation Center for Biomedicine, Medical Technology College, Shanghai University of Medicine \& Health Sciences, Shanghai 201318, China. ${ }^{3}$ Health Supervision Institute of Harbin Municipal Health Bureau, Harbin 150010, China.

Received: 21 May 2020 Accepted: 17 November 2020 Published online: 02 December 2020

\section{References}

1. Munns CF, Shaw N, Kiely M, Specker BL, Thacher TD, Ozono K, Michigami T, Tiosano D, Mughal MZ, Makitie $\mathrm{O}$ et al. Global consensus recommendations on prevention and management of nutritional rickets. J Clin Endocrinol Metab. 2016;101(2):394415. https:/doi.org/10.1210/jc.2015-2175.

2. Al-Jwadi RF, Jespersen E, Dalgard C, Bilenberg N, Christesen HT. S-25OHD is associated with hand grip strength and myopathy at 5 years in girls: an Odense child cohort study. J Clin Endocrinol Metab 2018; 103(7):2630-2639. https://doi.org/10.1210/jc.2018-00281.

3. Smith EM, Tangpricha V. Vitamin D and anemia: insights into an emerging association. Curr Opin Endocrinol Diabetes Obes. 2015;22(6):432-438. https://doi.org/10.1097/med.0000000000000199.

4. Zhang X, Ding F, Li H, Zhao W, Jing H, Yan Y, Chen Y. Low serum levels of vitamins $a, D$, and $E$ are associated with recurrent respiratory tract infections in children living in northern China: a case control study. PLoS One. 2016; 11(12):e0167689. https://doi.org/10.1371/journal.pone.0167689.

5. Wang LL, Wang HY, Wen HK, Tao HQ, Zhao XW. Vitamin D status among infants, children, and adolescents in southeastern China. J Zhejiang Univ Sci B. 2016;17(7):545-52. https://doi.org/10.1631/jzus.b1500285.

6. Peroni DG, Trambusti I, Di Cicco ME, Nuzzi G. Vitamin D in pediatric health and disease. Pediatr Allergy Immunol. 2020;31(Suppl 24):54-7. https://doi.org/10.1111/pai.13154.

7. National Research Cooperation Group on rickets prevention and treatment. Recommendation for prevention and treatment of rickets of vitamin $D$ deficiency in childhood (Chinese). Chin J Child Health Care. 2015;23(07): 781-2. https://doi.org/10.11852/zgetbjzz2015-23-07-35.

8. Okazaki R, Ozono K, Fukumoto S, Inoue D, Yamauchi M, Minagawa M, Michigami T, Takeuchi Y, Matsumoto T, Sugimoto T. Assessment criteria for vitamin $D$ deficiency/insufficiency in Japan: proposal by an expert panel supported by the research program of intractable diseases, Ministry of Health, Labour and Welfare, Japan, the Japanese Society for Bone and Mineral Research and the Japan Endocrine Society [opinion]. J Bone Miner Metab. 2017;35(1):1-5. https://doi.org/ 10.1007/s00774-016-0805-4

9. Schou AJ, Heuck C, Wolthers OD. Does vitamin D administered to children with asthma treated with inhaled glucocorticoids affect shortterm growth or bone turnover? Pediatr Pulmonol. 2003;36(5):399-404. https://doi.org/10.1002/ppul.10379.

10. Hradsky O, Soucek O, Maratova K, Matyskova J, Copova I, Zarubova K, Bronsky J, Sumnik Z. Supplementation with 2000 IU of cholecalciferol is associated with improvement of trabecular bone mineral density and muscle power in pediatric patients with IBD. Inflamm Bowel Dis. 2017;23(4): 514-523. https://doi.org/10.1097/mib.0000000000001047.

11. Uysalol M, Mutlu LC, Saracoglu GV, Karasu E, Guzel S, Kayaoglu S, Uzel N. Childhood asthma and vitamin D deficiency in Turkey: is there cause and effect relationship between them? Ital J Pediatr. 2013;39:78. https://doi.org/10.1186/1824-7288-39-78.

12. Misra M, Pacaud D, Petryk A, Collett-Solberg PF, Kappy M. Vitamin D deficiency in children and its management: review of current knowledge and recommendations. Pediatrics. 2008;122(2):398-417. https://doi.org/10.1542/peds.2007-1894.

13. Liu Y, Li X, Zhao A, Zheng W, Guo M, Xue Y, Wang P, Zhang Y. High prevalence of insufficient vitamin $D$ intake and serum 25 -hydroxyvitamin $D$ in chinese school-age children: a cross-sectional study. Nutrients. 2018;10(7). https://doi.org/10.3390/nu10070822.

14. Saggese G, Vierucci F, Prodam F, Cardinale F, Cetin I, Chiappini E, De' Angelis GL, Massari M, Del Giudice EM, Del Giudice MM et al. Vitamin $D$ in pediatric age: consensus of the Italian pediatric society and the Italian society of preventive and social pediatrics, jointly with the Italian federation of pediatricians. Ital J Pediatr. 2018;44(1): 51. https://doi.org/10.1186/s13052-018-0488-7.

15. Tao RX, Meng DH, Li JJ, Tong SL, Hao JH, Huang K, Tao FB, Zhu P. Current recommended vitamin $\mathrm{D}$ prenatal supplementation and fetal growth: results from the China-Anhui birth cohort study. J Clin Endocrinol Metab. 2018;103(1):244-252. https://doi.org/10.1210/jc.2017-00850.

16. O'Callaghan KM, Taghivand M, Zuchniak A, Onoyovwi A, Korsiak J, Leung $M$, Roth DE. Vitamin D in breastfed infants: systematic review of alternatives to daily supplementation. Adv Nutr. 2019;11(1):144-159. https://doi.org/10.1093/advances/nmz098.

17. Marwaha RK, Mithal A, Bhari N, Sethuraman G, Gupta S, Shukla M, Narang A, Chadda A, Gupta N, Sreenivas V, Ganie MA. Supplementation with three different daily doses of vitamin D3 in healthy pre-pubertal school girls: a cluster randomized trial. Indian Pediatr. 2018;55(11):951-6. https://doi.org/10.1007/s13312-018-1416-z. 
18. Xia. W, Zhang. Z, Lin. H, Jin. X, Wei. Y, Fu. Q. Consensus recommendations on vitamin D and their analogs (Chinese). Chin J Osteoporos Bone Miner Res. 2018;11(1):1-19. https://doi.org/10.3969/j.issn.1674-2591.2018.01.001.

19. Dobson R, Cock HR, Brex P, Giovannoni G. Vitamin D supplementation. Pract Neurol. 2018;18(1):35-42. https://doi.org/10.1136/practneurol-2017-001720.

20. Stepman HC, Vanderroost A, Van Uytfanghe K, Thienpont LM. Candidate reference measurement procedures for serum 25-hydroxyvitamin D3 and 25-hydroxyvitamin D2 by using isotope-dilution liquid chromatography-tandem mass spectrometry. Clin Chem. 2011;57(3):441448. https://doi.org/10.1373/clinchem.2010.152553.

21. Hu Y, Chen J, Wang R, Li M, Yun C, Li W, Yang Y, Piao J, Yang X, Yang L: Vitamin $D$ nutritional status and its related Factors for Chinese children and adolescents in 2010-2012. Nutrients. 2017;9(9). https://doi.org/10.3390/nu9091024.

22. Savastano S, Barrea L, Savanelli MC, Nappi F, Di Somma C, Orio F, Colao A: Low vitamin D status and obesity: role of nutritionist. Rev Endocr Metab Disord. 2017;18(2):215-225. https://doi.org/https://doi.org/10.1007/s11154-017-9410-7.

23. Chung $\mathrm{H}$, Kim HJ, Chung S, Yoo EG. Vitamin D deficiency in Korean children: prevalence, risk factors, and the relationship with parathyroid hormone levels. Ann Pediatr Endocrinol Metab. 2014;19(2):86-90. https://doi.org/10.6065/apem.2014.19.2.86.

24. Taseen K, Beaulieu G. Vitamin D levels and influencing predictors in refugee children in Sherbrooke (Quebec), Can Paediatr Child Health. 2017;22(6):307311. https://doi.org/10.1093/pch/pxx092.

25. Wang $S$, Shen G, Jiang $S, X u$ H, Li M, Wang Z, Zhang S, Yu Y. Nutrient status of vitamin D among chinese children. Nutrients. 2017;9(4). https://doi.org/10.3390/nu9040319.

26. Zhu Z, Zhan J, Shao J, Chen W, Chen L, Li W, Ji C, Zhao Z: High prevalence of vitamin $D$ deficiency among children aged 1 month to 16 years in Hangzhou, China BMC Public Health. 2012;12:126. https://doi.org/10.1186/1471-2458-12-126.

27. Science $M$, Maguire $J$, Russell ML, Smieja M, Walter SD, Loeb M. Prevalence and predictors of low serum 25-hydroxyvitamin D levels in rural Canadian children. Paediatr Child Health. 2017;22(3):125-129. https://doi.org/10.1093/pch/pxx007.

28. Satue M, Ramis JM, Monjo M. UV-activated 7-dehydrocholesterol-coated titanium implants promote differentiation of human umbilical cord mesenchymal stem cells into osteoblasts. J Biomater Appl. 2016;30(6):770779. https://doi.org/10.1177/0885328215582324.

29. Serrano MA. Contribution of sun exposure to the vitamin D dose received by various groups of the Spanish population. Sci Total Environ. 2018;619620:545-551. https://doi.org/10.1016/j.scitotenv.2017.11.036.

30. Greinert R, de Vries E, Erdmann F, Espina C, Auvinen A, Kesminiene A, Schuz J. European code against Cancer 4th edition: ultraviolet radiation and cancer. Cancer Epidemiol. 2015;39 Suppl 1:S75-S83. https://doi.org/10.1016/j.canep.2014.12.014.

31. Vierucci F, Del Pistoia M, Fanos M, Gori M, Carlone G, Erba P, Massimetti G, Federico G, Saggese G. Vitamin D status and predictors of hypovitaminosis D in Italian children and adolescents: a cross-sectional study. Eur J Pediatr. 2013; 172(12):1607-1617. https://doi.org/10.1007/s00431-013-2119-z.

32. Vitamin D Supplementation: recommendations for Canadian mothers and infants. Paediatr Child Health. 2007;12(7):583-598. https://doi.org/10.1093/ pch/12.7.583.

33. Braegger C, Campoy C, Colomb V, Decsi T, Domellof M, Fewtrell M, Hojsak I, Mihatsch W, Molgaard C, Shamir R et al. Vitamin D in the healthy European paediatric population. J Pediatr Gastroenterol Nutr. 2013;56(6):692-701. https://doi.org/10.1097/mpg.0b013e31828f3c05.

34. Holick MF, Binkley NC, Bischoff-Ferrari HA, Gordon CM, Hanley DA, Heaney RP, Murad MH, Weaver CM. Evaluation, treatment, and prevention of vitamin D deficiency: an Endocrine Society clinical practice guideline. J Clin Endocrinol Metab. 2011;96(7):1911-1930. https://doi.org/10.1210/jc.2011-0385.

35. Mo M, Wang S, Chen Z, Muyiduli X, Shen $Y$, Shao B, Li M, Chen D, Yu $Y$. A systematic review and meta-analysis of the response of serum 25hydroxyvitamin D concentration to vitamin D supplementation from RCTs from around the globe. Eur J Clin Nutr. 2019;73(6):816-834. https://doi.org/10.1038/s41430-019-0417-x.

36. Karin Z, Gilic B, Supe Domic D, Sarac Z, Ercegovic K, Zenic N, Uljevic O, Peric M, Markic J. Vitamin D status and analysis of specific correlates in preschool children: a cross-sectional study in southern Croatia. Int J Environ Res Public Health. 2018;15(11):2053. https://doi.org/10.3390/ijerph15112503.

37. Liang Y, Ren HY, Zuo PX. Associations between maternal nutrition knowledge, attitude, and practice and 25-hydroxyvitamin D levels and rickets in children in
Xinjiang province, People's Republic of China. Asia Pac J Public Health. 2018; 30(4):378-386. https://doi.org/10.1177/1010539518768034.

38. Day RE, Krishnarao R, Sahota P, Christian MS. We still don't know that our children need vitamin D daily: a study of parents' understanding of vitamin D requirements in children aged 0-2 years. BMC Public Health. 2019;19(1): 1119. https://doi.org/10.1186/s12889-019-7340-x.

39. Minkowitz B, Nadel L, McDermott M, Cherna Z, Ristic J, Chiu S. Obtaining vitamin $D$ levels in children with fractures improves supplementation compliance. J Pediatr Orthop. 2019;39(6):e436-e440. https://doi.org/10.1097/ bpo.0000000000001363.

40. Petersen RA, Larsen LH, Damsgaard CT, Sorensen LB, Hjorth MF, Andersen R, Tetens I, Krarup H, Ritz C, Astrup A et al. Common genetic variants are associated with lower serum 25-hydroxyvitamin D concentrations across the year among children at northern latitudes. Br J Nutr. 2017;117(6):829-838. https://doi.org/10.1017/s0007114517000538.

41. Holick MF. The vitamin D deficiency pandemic: approaches for diagnosis, treatment and prevention. Rev Endocr Metab Disord. 2017;18(2):153-165. https://doi.org/10.1007/s11154-017-9424-1.

42. Reichrath J, Saternus R, Vogt T. Challenge and perspective: the relevance of ultraviolet (UV) radiation and the vitamin D endocrine system (VDES) for psoriasis and other inflammatory skin diseases. Photochem Photobiol Sci. 2017:16(3):433-444. https://doi.org/10.1039/c6pp00280c.

\section{Publisher's Note}

Springer Nature remains neutral with regard to jurisdictional claims in published maps and institutional affiliations.
Ready to submit your research? Choose BMC and benefit from:

- fast, convenient online submission

- thorough peer review by experienced researchers in your field

- rapid publication on acceptance

- support for research data, including large and complex data types

- gold Open Access which fosters wider collaboration and increased citations

- maximum visibility for your research: over $100 \mathrm{M}$ website views per year

At BMC, research is always in progress.

Learn more biomedcentral.com/submissions 